\title{
Conservative treatment effects on spinal deformities revealed by surface topography - a critical review of literature
} Hans-Rudolf Weiss

\author{
Address: Asklepios Katharina Schroth Spinal Deformities Rehabilitation Centre, Bad Sobernheim, Germany \\ from $5^{\text {th }}$ International Conference on Conservative Management of Spinal Deformities \\ Athens, Greece. 3-5 April 2008 \\ Published: 15 January 2009 \\ Scoliosis 2009, 4(Suppl I):OI7 doi:I0.II86/I748-7|6I-4-SI-OI7
}

This abstract is available from: http://www.scoliosisjournal.com/content/4/SI/OI7

(C) 2009 Weiss; licensee BioMed Central Ltd.

\section{Background}

Surface topography systems are on the market today promising a reduction of radiation in the management of patients with spinal deformities as well as the detection of static deviations which are supposed to cause pain.

\section{Materials and methods}

A review of literature has been undertaken to investigate the usefulness of rasterstereography applied to reveal treatment effects of conservative treatment of spinal deformities. In the video rasterstereography (Formetric ${ }^{\oplus}$ system), the whole object is illuminated by a pattern of parallel lines, recorded in a single frame and needing only a short measurement time $(40 \mathrm{msec})$. The automatic image processing consists of the identification of the raster lines and automatic 3-D reconstruction of the back; shape analysis is performed by a computer. Parameters used to compare the short-term effects of the different treatment concepts described were average lateral deformation (root mean square [rms]) with a technical error of $3 \mathrm{~mm}$ and average surface rotation (rms) with a technical error of $1,5^{\circ}$.

\section{Results}

Eight reports have been found where the effects of conservative treatment were evaluated using these outcome parameters. The average changes were greater than technical error in only two of the studies, while in the others significant changes have been revealed in part.

\section{Conclusion}

Video rasterstereography seems helpful for scientific investigations. However, the margins of technical error are far too high to draw conclusions in the individual case, especially in patients with scoliosis.

\section{References}

I. Weiss HR, Verres Ch, El Obeidi N: Ermittlung der Ergebnisqualität der Rehabilitation von Patienten mit Wirbelsäulendeformitäten durch objektive Analyse der Rückenform. Phys Rehab Kur Med 1999, 9:4I-47.

2. Weiss HR, Steiner A, Reichel D, Petermann F, Warschburger P, Freidel K: Medizinischer Outcome nach stationärer Intensivrehabilitation bei Skoliose. Phys Med Rehab Kuror 200 I, I I:I00-103.

3. Schmitz A, Gäbel H, Weiss HR, Schmitt O: Anthropometrische Datenerhebung mittels 3D-Ganzkörperscan bei idiopathischer Skoliose. Z Orthop 2002, 140:632-636. 